1 Observation of nest visitation by multiple males in the European

*Padget, O. ${ }^{1,2}$, Morford, J. ${ }^{1}$, Ward, A. ${ }^{2}$, Zamora-Marín, J.M. ${ }^{3,4}$, Zamora-López, A. ${ }^{3,4}$, León-

Ortega, M. ${ }^{3,5}$, García-Castellanos, F.A. ${ }^{3}$ and Lowe, A. ${ }^{2}$

${ }^{1}$ Department of Zoology, Zoology Research and Administration Building, 11a Mansfield Rd., Oxford, 8 Ox1 3SZ, U.K.

$9 \quad{ }^{2}$ Birklands Ringing Group, Mansfield, Nottinghamshire, U.K.

$10{ }^{3}$ ANSE Bird Ringing Group, Association of Naturalists of the Southeast, Murcia, Spain

$11{ }^{4}$ Department of Zoology and Physical Anthropology, Faculty of Biology, University of Murcia, Spain

${ }^{5}$ Department of Ecology and Hydrology, Faculty of Biology, University of Murcia, Spain

*Author for correspondence: oliver.padget@zoo.ox.ac.uk

Summary

We report observations of nest visitation of multiple males to three nests of European nightjar. In one case, we report the direct observation of two males apparently exhibiting parental behaviour at the same nest. In two other cases, second males visited nests. We consider the potential functions of nest visits by extra-pair males in the nightjar.

\title{
Body
}

European Nightjars, Caprimulgus europeaus, were intensively monitored throughout the 2018 breeding season from May $1^{\text {st }}$ to September $1^{\text {st }}$ on Canford Heath NNR $(50.76251 \mathrm{~N},-1.95773 \mathrm{~W})$,

Dorset. Nine nests were monitored as part of an ongoing radio-telemetry study, involving trapping birds on or close to nests and recording a subset of nest provisioning behaviours using hidden trail cameras at the nest. We recorded three nests that had at least two male attendees. We do not know, however, that the remaining six were attended by only one male. 
Nest 1:

31 The nest was found by on $13^{\text {th }}$ June radio tracking a $2^{\text {nd }}$ calendar year $(\mathrm{CY})$ male and then searching in nearby suitable habitat. A female $\left(3^{\text {rd }} \mathrm{CY}\right.$ or greater $)$ was incubating at the nest $5 \mathrm{~m}$ from the roosting male. A camera trap was setup where this tagged male was photographed relieving the female of incubation during early evening. Once the eggs hatched, an attempt was made to recapture the male whilst at the nest during which a new, un-ringed male ( $3^{\text {rd }} \mathrm{CY}$ or greater) was caught at the nest by hand. The new male was alone with two five-day old chicks at the nest. The original male was then caught at the nest by mist netting in the following week.

\section{Nest 2:}

The nest was found by radio tracking a female $\left(3^{\text {rd }} \mathrm{CY}\right.$ or greater) to the nest where she was incubating.

41 Once the chicks hatched, a male $\left(2^{\text {nd }} \mathrm{CY}\right.$ ) was caught entering the nest by mist-netting (without playback lure) at the nest. A second male ( $3^{\text {rd }} \mathrm{CY}$ or greater) was then caught by being flushed off the nest, where it was with two chicks, into the net the same night, 15 minutes after the first male was caught. The second male was radio-tracked and, following nest failure, re-nested with the same female $50 \mathrm{~m}$ from the original nest site.

\section{Nest 3:}

48 The nest was found by radio tracking a female $\left(2^{\text {nd }} \mathrm{CY}\right)$ to the nest where she was incubating. Once

49 the chicks hatched, a male $\left(3^{\text {rd }} \mathrm{CY}\right.$ or greater) and female were caught at the nest by mist-netting. A second male of unknown age was observed arriving at the nest, within $2 \mathrm{~m}$ of the nest whilst the first

51 male and female were being processed.

Here we report a small sample of nests with relatively high frequency (at least 1/3) of nest attendance by multiple male nightjars during the same reproductive attempt, across a single season at a single site with a large population of European nightjars. Why second male nightjars might have visited 
nests is unknown, but nest visitation by birds outside of socially monogamous pairings are well known previously across a wide variety of avian taxa (Firth et al. 2018), and we explore some of the potential explanations for this behaviour in nightjars here. First, males might visit nests to secure copulations with females that become receptive for a second breeding attempt during the first, as occurs in some other species ( e.g. great tits, Parus major Firth et al. 2018). Indeed, whilst the European nightjar is generally considered to have socially monogamous nesting behaviour, mate switching may occur between broods or between seasons (Alexander and Cresswell 1990), the former of which might result in males seeking copulations with females before chick fledging from a first brood. A speculative extension to this is that nest visitations might, in addition, be involved in displays to a prospective mate, if for example females attend to males' parenting skill at the nest as part of mate selection. Alternatively, male nightjars might be visiting nests in order to acquire information about other individuals, or their nest sites, in nearby areas (Firth et al., 2018; Hebert et al. 2011; Schuett et al. 2017). In pied flycatchers, Ficedula hypoleuca, such nest visitation seems to be associated most frequently with nests that have fledged large numbers of offspring and thus is thought to be driven by birds seeking to trade-up nest site quality (Schuett et al. 2017). Lastly, nest visits might be in order to provision offspring or incubate eggs. In the current study, nest visitation at the first nest by one male was observed at dusk, typical of nightjar parental behaviour during incubation (Ferguson-Lees et al. 2011) and, by the second male, was apparently to brood two chicks. Tentatively, these observations are most consistent with the provisioning hypothesis. Such nest provisioning might, in conjunction with previously observed mate guarding behaviour in the species (Sáez \& Camacho 2016), suggest that male nightjars are responding to polyandrous extra-pair copulations owing to the prospect of shared or probabilistic paternity of the clutch (Jennions and Petrie 2000). Whilst multiple males might also engage in provisioning behaviour at nests owing to relatedness (and relatedness could be high for species with high natal philopatry (Camacho 2014)), such cooperative breeding is rare across avian taxa (Cockburn 1998). Resolving these and other hypotheses for why nightjars exhibit extra-pair nest visitation will require more intensive monitoring and, most probably, genetic 
studies in future.

\section{Ethical statement}

All work was carried out under licence from the British Trust for Ornithology (C/6128).

\section{Acknowledgements}

We would like to thank W.H. White Ltd., for funding the study and logistical support, Brian Cresswell for useful discussions and Terry Elborne for useful discussions and help in the field. The study was carried out with permission from the Borough of Poole Natural Habitats Dept., whom we thank also. We also thank to Carlos Camacho and Pedro Sáez for valuable contributions to latest version of the manuscript.

\section{References}

Alexander, I., and Cresswell, B. (1990). Foraging by nightjars, Caprimulgus europeaus away from their nesting areas. Ibis. 132(4). 568-574.

Camacho, C. Early age at first breeding and high natal philopatry in the Red-necked Nightjar Caprimulgus ruficollis. (2014) Ibis. 156. 442-445.

Cockburn, A. (1998). Evolution of helping behaviour in cooperatively breeding birds. Annual Review of Ecology and Systematics. 29. 141-177.

Firth, J.A., Verhelst, B.L., Crates, R.A., Garroway, C.J. and Sheldon, B. (2018). Spatial, temporal and individual-based differences in nest-site visits and subsequent reproductive success in wild great tits. Journal of Avian Biology. 49 (10). 1-11.

Hebert, P.N., Carter, H.R., and Golightly, R. (2011). Extra-pair visitations to a marbled murrelet nest in Northern California. Northwestern Naturalist. 92. 95-100.

Jennions, M.D., Petrie, M. (2000). Why do females mate multiply? A review of the genetic benefits.

\section{Biological Reviews. 75 (1). 21-64.}


108 Jensen, N.O. (2013). A case of polyterritorial polygyny in European Nightjar Caprimulgus europaeus.

109 Dansk Ornitologisk Forening. 108. 239-244.

110 Schuett, W., Järvistö, P.E., Calbim, S., Velmala, W. and Laaksonen, T. (2017). Nosy neighbours: large

111 broods attract more visitors. A field experiment in the pied flycatcher, Ficedula hypoleuca. Oecologia, $112184(1) .115-126$.

113 Sáez, P. and Camacho, C. (2016). Chotacabras cuellirrojo - Caprimulgus ruficollis. En: Enciclopedia 114 Virtual de los Vertebrados Españoles. Salvador, A., Morales, M. B. (Eds.). Museo Nacional de 115 Ciencias Naturales, Madrid.http://www.vertebradosibericos.org/ 